\title{
Single Nucleotide Polymorphism of TBC1D1 Gene Association with Growth Traits and Serum Clinical-Chemical Traits in Chicken
}

\author{
Prabuddha Manjula ${ }^{1^{*}}$, Sunghuyn $\mathrm{Cho}^{1^{*}}$, Kook Jin $\mathrm{Suh}^{2}$, Dongwon $\mathrm{Seo}^{3}$ and Jun Heon Lee ${ }^{4^{\dagger}}$ \\ ${ }^{1}$ Graduate Student, Division of Animal and Dairy Science, Chungnam National University, Deajeon 34134, Republic of Korea \\ ${ }^{2}$ Student, Division of Animal and Dairy Science, Chungnam National University, Deajeon 34134, Republic of Korea \\ ${ }^{3}$ Research Professor, Division of Animal and Dairy Science, Chungnam National University, Deajeon 34134, Republic of Korea \\ ${ }^{4}$ Professor, Division of Animal and Dairy Science, Chungnam National University, Deajeon 34134, Republic of Korea
}

ABSTRACT TBC1D1 gene has known functional effects on body energy homeostasis and glucose uptake pathway in skeletal muscle tissue. This biological function is reported to have significant effects on traits of growth and meat quality in chicken. In this study, we focused on two single nucleotide polymorphisms (SNPs) (g.70179137A $>$ G and g.70175861T $>$ C) identified through SNP annotation information of Korean native chicken and previous literature for TBC1D1 in chicken. Association of SNPs in TBC1D1 with growth and serum clinical-chemical traits were evaluated. A total of 584 male and female birds from five Korean native chicken lines were used in the study. The SNP1 (g.70179137A $>$ G) is located in intron 11 and SNP2 (g.70175861T $>$ C) is a non-synonymous missense mutation in exon 10, responsible for the amino acid change from Methionine to Valine. The A allele of SNP1 and T allele of SNP2 had the highest allele frequencies. Both SNPs indicated moderate polymorphism information content values $(0.25<\mathrm{PIC}<0.5)$. Association results shown that $\mathrm{SNP} 1$ was significantly associated with BW00, BW20, GR14-16 and carcass weight $(P<0.05)$. The AA genotype had higher value for all these traits except BW00. Whereas, genotype GG have lower values for BW20, GR14-16, GR18-20 and carcass weight. The sGOT level was significant with SNP1 but not with the SNP2. The GG genotype had the highest sGOT value and AG reported the lowest. BW20 was significantly associated with SNP2 $(P<0.05)$. The body weight and carcass weight values of $\mathrm{CC}$ and TC genotypes were higher than those of TT genotype.

(Key words: association, chicken, growth trait, TBC1D1 gene)

\section{INTRODUCTION}

Application of genetic markers for precise and fast identification of potential candidate genes for quantitative traits in livestock have been reported in several studies (Hocking, 2005; Zhu and Zhao, 2007). Identification and application of such genes for selection of livestocks through marker assistance selection (MAS) is now become a norm in livestock breeding program (Dekkers and van der Werf, 2007). This is because the use of genomic information can increase accuracy and selection rate. Therefore, increase the selection response. Van der Beek and van Arendonk (1996) have estimated that an additional total selection response of $6 \%$ to $13 \%$ when using MAS that incorporate the markers linked the quantitative trait loci (QTL) after five generation of selection. More recently, genome wide association test to identify the

* These authors have contributed equally to this work.

† To whom correspondence should be addressed : junheon@cnu.ac.kr causal mutation and underlying genes, which describe the large variation of production traits in livestocks including poultry, were reported for many commercial and domestic crossbreeds (Cahyadi et al., 2014). Particularly, QTLs that highly responsible for chicken growth and carcass traits were located on several major chromosomal regions, GGA1, 2, and 4 for the broiler Leghorn cross (Zhou et al., 2006), GGA1, 2, 4, 10 for Hampshire and white Leghorn chicken line (Nassar, Goraga and Brockmann, 2015), GGA3, 4, 19 and 20 for Korean native chicken lines (Cahyadi et al., 2016).

Among the reported candidate genes from several QTLs in the distal region of GGA4 and by genome wide studies, the TBC1D1 gene was identified as a one of functional candidate genes that responsible for obesity, growth in mammals, and livestock animals including chicken (Gu et al., 2011; Nassar et al., 2015). During the domestication of chicken and sub- 
sequent specialization to broiler and layer lines, some of the genes in domestic lines were undergone important selective sweep related to the growth. Recent whole-genome resequencing studies identified that the TBC1D1 gene was among those reported sweeps for commercial broilers (Rubin et al., 2010; Fan et al., 2013).

The Rab-GTPase-activating protein (TBC1D1) was first revealed as a protein, regulating cell differentiation and growth in a screen of a murine mast cell library (Dokas, 2016). TBC1D1 is belongs the Rab-GAP protein family that transmitting specific signals that stimulate biological effects on glucose uptake in skeletal muscle. Variants in the TBC1D1 gene have been significantly associated with fat and lean meat deposition and energy homeostasis in pig (Fontanesi et al., 2011; Howard et al., 2015). Similarly, in rabbit variant (c. $214 \mathrm{G}>\mathrm{A}$ ) in exon 1 was significantly associated with body weight at 35 and 56 days (Yang et al., 2013). In several other researches, variants in this gene were associated with obesityrelated traits in mice and body mass index in human (Stone et al., 2006; Dokas et al., 2016). Possible functional involvement of TBC1D1 gene in chicken was described in Wang et al. (2014). A significant genomic region that affecting growth from 5 to 20 weeks age was recorded at the lateral region of GGA4, between 153 and $159 \mathrm{cM}(61.5 \sim 88.4 \mathrm{Mb}$ size $)$ harbor the TBC1D1 gene (Nassar et al., 2015).

Therefore, the aim of this current study was to investigate effect of two SNP variant on growth traits (zero weeks to 20 weeks, weight gain from GR0-2 weeks $\sim$ GR18-20 weeks), weight at slaughter, carcass weight and serum chemical traits in Korean native chicken (KNC).

\section{MATERIAL AND METHODS}

\section{Animal and Data Collection}

This experiment was performed in agreement with "The Guide for the Care and Use of Laboratory Animals," published by the Institutional Animal Care and Use Committee of the National Institute of Animal Science (NIAS) (2012-C037), Republic of Korea. A total of 597 chickens of $F_{1}$ generation representing 70 half sib families from $88\left(\mathrm{~F}_{0}\right)$ parents of Korean native chicken (15 sires \& 73 Dams) were used. Finally, we used 584 birds from total of 597 birds; Gray-Brown $(\mathrm{G}=110)$, Black ( $\mathrm{L}=88)$, Red-Brown $(\mathrm{R}=135)$, White $(\mathrm{W}=121)$ and Yellow-Brown $(\mathrm{Y}=130)$ for the analysis. All the birds were reared with the same feeding and environment conditions provided by the NIAS. Growth traits; body weight (BW) from zero weeks to 20 weeks, weight at slaughter (recorded after given fasting time) were reported. Weight gain (GR) at 2 week interval was calculated. Carcass weight and eight serum clinical-chemical traits were measured and described in previous study are included for this study (Seo et al., 2016).

\section{Genotyping using KASP Assay}

Genomic DNA was isolated from the whole blood samples following standard manual procedure and concentrations were measured using a NanoDrop ${ }^{\circledR} 2000 \mathrm{C}$ spectrophotometer (Thermo Scientific, USA). The TBC1D1 gene was selected as a functional candidate gene in QTL region that have identified in several studies and SNP variations described in this study were obtained via filtering the Korean native chicken whole genome SNP annotation information. SNP target specific primers were prepared for KASP genotyping assay (Table 1). Both parent and progeny samples were genotyped by KASP genotyping assay and compared to validate the genotype states of $F_{1}$ birds.

\section{Statistical Analysis}

Genotype data and quantitative data were prepared in excel

Table 1. Primer information for SNP genotyping for chicken TBC1D1 gene by KASP genotyping assay

\begin{tabular}{|c|c|c|c|c|c|c|}
\hline Gene & Marker & rs_number & $\begin{array}{l}\text { Mutation } \\
\text { type }\end{array}$ & $\begin{array}{l}\text { Forward primer } \mathrm{X}, \mathrm{Y} \\
\qquad\left(5^{\prime}-3^{\prime}\right)\end{array}$ & $\begin{array}{l}\text { Reverse primer } \\
\qquad\left(5^{\prime}-3^{\prime}\right)\end{array}$ & $\begin{array}{l}\text { Fluorescent color } \\
\text { (wild/mutant) }\end{array}$ \\
\hline \multirow{2}{*}{$\begin{array}{l}\text { TBC1D1 } \\
\text { gene }\end{array}$} & Primer1 & rs80645709 & Intron var & $\begin{array}{l}\text { CAAAATTATGGTCAGAGGCAATAAACACA/ } \\
\text { AAATTATGGTCAGAGGCAATAAACACG }\end{array}$ & $\begin{array}{l}\text { GATCTCTGACGGAA } \\
\text { TCGTTTGAAAGTATT }\end{array}$ & $\begin{array}{c}\text { A / G } \\
(\text { FAM/HEX) }\end{array}$ \\
\hline & Primer2 & rs14742436 & Missense & $\begin{array}{l}\text { GGTCACTGGAAAGATCACCCAC/ } \\
\text { GGGTCACTGGAAAGATCACCCAT }\end{array}$ & $\begin{array}{l}\text { GAGAATGCTGTCAA } \\
\text { GAGCAGTGGAT }\end{array}$ & $\begin{array}{c}\mathrm{C} / \mathrm{T} \\
(\mathrm{FAM} / \mathrm{HEX})\end{array}$ \\
\hline
\end{tabular}


and $\mathrm{R}$ softwares. Descriptive statistics for phenotypic data were obtained using MINITAB version 14 (MINITAB Inc., USA). Gene frequencies were determined for each SNP in total population by using population genetics package "genetics” implemented in R (Warnes, 2015). Statistical analyses for association between meat quality traits and genotypes were performed based on mean adjusted performance of the progeny using general linear model procedure (GLM) in MINITAB version 14. Association analyses were performed separately using single SNP approach, following the linear mixed models describes in below.

$$
\begin{aligned}
& \mathrm{Y}_{\mathrm{ijkmn}}=\mu+\mathrm{S}_{\mathrm{i}}+\mathrm{L}_{\mathrm{j}}+\mathrm{B}_{\mathrm{k}}+\text { Sire }_{\mathrm{m} \text { (line) }}+\operatorname{Dam}_{\mathrm{n} \text { (line, Sire) }}+ \\
& \mathrm{M}_{\mathrm{m}}+\mathrm{e}_{\mathrm{ijkmn}}
\end{aligned}
$$

Where, $Y_{\mathrm{ijklmn}}$ was the trait measured on each animal. $\mu$ was the overall mean of observation, $S_{i}$ was gender effect, $L_{j}$ was the line effect, $B_{k}$ was fixed effect due to the $\mathrm{K}^{\text {th }}$ batch, Sire $_{\mathrm{m}}$ (line) was the fixed effect of $\mathrm{m}^{\text {th }}$ sire nested in $\mathrm{j}^{\text {th }}$ line. $\operatorname{Dam}_{n}$ (line, sire) was the effect of $n^{\text {th }}$ dams nested in $\mathrm{j}^{\text {th }}$ line and $\mathrm{m}^{\text {th }}$ sire in the population and $\mathrm{M}_{\mathrm{m}}$ was the fixed effect of $\mathrm{m}^{\text {th }}$ genotype. $\mathrm{e}_{\mathrm{ijklmn}}$ was the random residual error. Model I was used for growth traits and weight at slaughter. For the serum clinical-chemical traits, following model (II) was used with fixed effect of fasting time $\left(\mathrm{FT}_{1}\right)$. Statistical significance was tested and pairwise comparison of means were obtained using Tukey test. Mean differences were considered significant at $95 \%(P<0.05)$ confidence level.

$$
\begin{aligned}
\mathrm{Y}_{\mathrm{ijklmn}}= & \mu+\mathrm{S}_{\mathrm{i}}+\mathrm{L}_{\mathrm{j}}+\mathrm{B}_{\mathrm{k}}+\mathrm{FT}_{1}+\text { Sire }_{\mathrm{m} \text { (line) }}+ \\
& \text { Dam }_{\mathrm{n} \text { (line, Sire) }}+\mathrm{M}_{\mathrm{m}}+\mathrm{e}_{\mathrm{ijklmn}}
\end{aligned}
$$

\section{RESULTS AND DISCUSSION}

\section{Genotype and Allele Frequencies}

Two selected SNPs from the KNC SNP annotation data (g.70179137A $>$ G and g.70175861T $>$ C ) were evaluated. Table 2 described the genotype and allele frequencies of two SNPs. For SNP1 (A/G), A allele has highest allele frequency of 0.54 and for the SNP2 (T/C) C allele had the highest value (0.56). Especially, the SNP2 is a nonsynonymous missense mutation responsible for amino acid change from Methionine to Valine (ATG/GTG) (https://asia.ensembl.org/). Previously, Wang et al. (2014) reported the same SNP2 (g.69340192G>A), but in the form of complementary strand that may be based on the Gallus gallus 4.0 reference genome. Compare to our population, allele frequencies of SNP2 in his study population were similar for both allele (0.5). In our study, we reported moderate polymorphic information content (PIC) values for both SNPs (0.374 and 0.372 respectively).

\section{Association Analysis}

There are very few studies discussed the TBC1D1 gene polymorphisms and their potential associations with growth traits in chicken despite the potential QTL region that included the TBC1D1 as a candidate gene. Therefore, our objective of this study is to evaluate the selected two SNPs, especially the effect of SNP2 that has been shown significant relationship in Erlang chicken (Wang et al., 2014). We used body weight (BW) data from zero to 20 weeks of age and weight gain

\begin{tabular}{|c|c|c|c|c|c|c|c|}
\hline SNP marker & Type & \multicolumn{3}{|c|}{ Genotype frequency } & \multicolumn{2}{|c|}{ Allele frequency } & PIC value ${ }^{1}$ \\
\hline SNP1 & \multirow[b]{2}{*}{ Intron var. } & AA & $\mathrm{AG}$ & GG & A & G & \multirow[b]{2}{*}{0.374} \\
\hline $\begin{array}{c}\text { g. } 70179137 \mathrm{~A}>\mathrm{G} \\
\text { rs } 80645709\end{array}$ & & $181(0.31)$ & $261(0.45)$ & $139(0.24)$ & $623(0.54)$ & $539(0.46)$ & \\
\hline SNP2 & \multirow{2}{*}{$\begin{array}{c}\text { Missense. } \\
\text { (ATG/GTG) }\end{array}$} & $\mathrm{CC}$ & $\mathrm{TC}$ & TT & $\mathrm{C}$ & $\mathrm{T}$ & \multirow[b]{2}{*}{0.372} \\
\hline $\begin{array}{l}\text { g. } 70175861 \mathrm{~T}>\mathrm{C} \\
\text { rs } 14742436\end{array}$ & & $206(0.35)$ & $235(0.40)$ & $140(0.24)$ & $647(0.56)$ & $515(0.44)$ & \\
\hline
\end{tabular}
calculated at the two weeks interval. In addition, weight at slaughter (SLW) and carcass weight (CW) and eight serum clinical-chemical traits were included. The descriptive statistics

Table 2. Genotype and allele frequencies for SNPs in TBC1D1 gene

${ }^{1}$ PIC: Polymorphic information content. 
for all the traits described in Table $3 \&$ Table 4, respectively.

Least square means of traits after corrected for all the fixed effects were statistically evaluated. The growth trait results showed that SNP1 was significant for BW00, BW20, GR14-16, and CW $(P<0.05)$ (Table 5). SNP1 given significant association with Glutamate Oxaloacetate transaminase (sGOT) level in blood serum but not with the SNP2 (Table 6).

However, the SNP 2 was reported significant association

Table 3. Descriptive statistics for growth traits in Korean native chicken

\begin{tabular}{|c|c|c|c|}
\hline Trait $(\mathrm{g})^{1}$ & $\mathrm{~N}$ & Mean & $\pm \mathrm{SE}$ of mean \\
\hline BW00 & 581 & 38.39 & 0.21 \\
\hline BW02 & 574 & 143.76 & 1.03 \\
\hline BW04 & 579 & 265.52 & 2.91 \\
\hline BW06 & 581 & 426.47 & 5.42 \\
\hline BW08 & 579 & 607.09 & 8.08 \\
\hline BW10 & 580 & 767.40 & 9.17 \\
\hline BW12 & 579 & 991.30 & 11.50 \\
\hline BW14 & 580 & $1,179.40$ & 12.30 \\
\hline BW16 & 581 & $1,383.00$ & 13.90 \\
\hline BW18 & 581 & $1,587.80$ & 14.30 \\
\hline BW20 & 581 & $1,780.20$ & 15.30 \\
\hline SLW & 581 & $1,694.30$ & 15.10 \\
\hline $\mathrm{CW}$ & 577 & 998.95 & 9.94 \\
\hline GR0-2 & 574 & 105.41 & 0.98 \\
\hline GR2-4 & 580 & 123.01 & 2.03 \\
\hline GR4-6 & 580 & 161.46 & 2.75 \\
\hline GR6-8 & 579 & 180.73 & 2.98 \\
\hline GR8-10 & 577 & 160.44 & 2.88 \\
\hline GR10-12 & 578 & 223.54 & 3.89 \\
\hline GR12-14 & 578 & 188.25 & 3.76 \\
\hline GR14-16 & 572 & 209.24 & 3.22 \\
\hline GR16-18 & 578 & 205.99 & 4.56 \\
\hline GR18-20 & 579 & 190.98 & 3.04 \\
\hline
\end{tabular}

${ }^{1}$ body weight from zero weeks to 20 weeks (g), SLW: weight at slaughter (g), CW: Carcass weight (g), GR0-2 GR18-20: weight gain $(\mathrm{g})$.
Table 4. Descriptive statistics for serum clinical-chemical traits in Korean native chicken

\begin{tabular}{cccc}
\hline \hline Trait & $\mathrm{N}$ & Mean & \pm SE of mean \\
\hline Glu & 581 & 255.97 & 1.12 \\
T-Pro & 579 & 4.2154 & 0.0260 \\
GPT & 581 & 2.9254 & 0.0173 \\
Cre & 581 & -0.228 & 0.0134 \\
HDL_C & 581 & 96.41 & 1.25 \\
T-Cho & 579 & 134.8 & 1.53 \\
GOT & 579 & 5.3959 & 0.00950 \\
Amy & 572 & 5.3681 & 0.0130 \\
\hline
\end{tabular}

Glu: glucose (mg/dL), T-Pro: total protein (g/dL), GPT: glutamicpyruvic transaminase (IU/L), Cre: creatinine $(\mathrm{mg} / \mathrm{dL}), \mathrm{HDL}_{-} \mathrm{C}$ : high density lipoprotein cholesterol (mg/dL), T-Cho: total cholesterol $(\mathrm{mg} / \mathrm{dL})$, GOT: glutamic oxaloacetic transaminase, Amy: amylase (IU/L).

with BW20 $(P<0.05)$ (Table 5). Interestingly, the SNP2 reported to have significant associated with live weight, carcass weight, and several other meat quality traits in Erlang mountainous chicken (Wang et al., 2014). Most of the body weight traits and serum clinical-chemical traits were not significant (Table 6). Moreover, serum glucose level was not significant for both SNPs.

Peng et al. (2015) showed that higher TBC1D1 mRNA expression in thigh muscle, and abdominal fat at 10 and 13 weeks of age in male chicken compare to that of female birds. To evaluate sex effects on this gene, the interaction between sex, line and genotype was tested. However, no significant relationship was identified.

In our study population, SNP1 for BW20, GR14-16, GR18-20 and CW, genotype AA have higher value. Whereas, GG genotype was responsible for lower values of these traits. AG genotype shown average values for these traits. This indicated that A allele has the favorable effects on the growth traits.

On the other hand, CC genotype of SNP2 was shown higher value for BW20, GR14-16 and CW. Moreover, TT was responsible for the lowest value and genotype TC was moderate effect. Therefore, it is clear that $\mathrm{C}$ allele is favorable for traits in F1 progeny of KNC. Similarly, Wang 
Table 5. Least square means for growth traits in Korean native chicken

\begin{tabular}{|c|c|c|c|c|}
\hline${ }^{1}$ Trait & \multicolumn{3}{|c|}{${ }^{2}$ Least square mean $( \pm \mathrm{SE})$} & \multirow[t]{2}{*}{$P$-value } \\
\hline rs80645709 (SNP1) & AA & AG & GG & \\
\hline BW00 & $38.40 \pm 0.2265^{\mathrm{b}}$ & $38.48 \pm 0.1769^{b}$ & $39.25 \pm 0.266^{\mathrm{a}}$ & 0.025 \\
\hline BW20 & $1,797 \pm 18.43^{\mathrm{a}}$ & $1,776 \pm 14.39^{\mathrm{a}}$ & $1,719 \pm 21.69^{b}$ & 0.027 \\
\hline GR14-16 & $226.8 \pm 6.37^{\mathrm{a}}$ & $206.7 \pm 5.06^{\mathrm{b}}$ & $192.5 \pm 7.64^{\mathrm{b}}$ & 0.004 \\
\hline GR18-20 & $204.4 \pm 6.56$ & $190.6 \pm 5.10$ & $179.3 \pm 7.688$ & 0.06 \\
\hline $\mathrm{CW}$ & $1,011.8 \pm 12.45^{\mathrm{a}}$ & $989.9 \pm 9.72^{\mathrm{ab}}$ & $959.4 \pm 14.62^{b}$ & 0.036 \\
\hline rs14742436 (SNP2) & $\mathrm{CC}$ & $\mathrm{TC}$ & TT & \\
\hline BW20 (g) & $1,795 \pm 16.90^{\mathrm{a}}$ & $1,773 \pm 15.37^{\mathrm{ab}}$ & $1,724 \pm 21.44^{b}$ & 0.039 \\
\hline GR14-16 & $218.4 \pm 5.90$ & $210.5 \pm 5.41$ & $196.6 \pm 7.54$ & 0.08 \\
\hline $\mathrm{CW}$ & $1,009.7 \pm 11.41^{\mathrm{a}}$ & $987.4 \pm 10.39^{\mathrm{ab}}$ & $962.7 \pm 14.45^{\mathrm{b}}$ & 0.048 \\
\hline
\end{tabular}

${ }^{1}$ BW00: body weight at zero weeks (g), BW20: body weight at 20 weeks (g), CW: carcass weight (g), GR14-16: weight gain from 14weeks to 16 weeks (g), GR18-20: weight gain from 18 weeks to 20 weeks $(\mathrm{g})$.

${ }^{2}$ Least square means for growth traits adjusted for fixed effect.

${ }^{\mathrm{a}, \mathrm{b}}$ Means within a row with no common superscript differ significantly $(P<0.05)$.

Table 6. Least square means for serum clinical-chemical traits in Korean native chicken

\begin{tabular}{|c|c|c|c|c|c|}
\hline \multirow[t]{2}{*}{ Gene/ marker } & \multirow[t]{2}{*}{${ }^{11}$ Trait } & \multicolumn{3}{|c|}{ 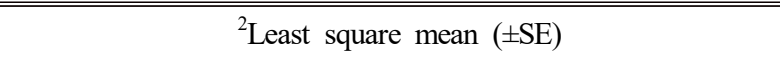 } & \multirow[t]{2}{*}{ Association $P$-value } \\
\hline & & AA & $\mathrm{AG}$ & GG & \\
\hline \multirow{8}{*}{$\begin{array}{c}\text { SNP1 } \\
\text { rs } 80645709\end{array}$} & Glu & $256.7 \pm 6.406$ & $256.4 \pm 5.055$ & $240.8 \pm 9.532$ & 0.633 \\
\hline & T-Pro & $4.026 \pm 0.150$ & $4.249 \pm 0.118$ & $4.196 \pm 0.223$ & 0.224 \\
\hline & GPT & $2.873 \pm 0.089$ & $2.836 \pm 0.071$ & $3.094 \pm 0.133$ & 0.395 \\
\hline & Cre & $-0.241 \pm 0.071$ & $-0.373 \pm 0.056$ & $-0.165 \pm 0.105$ & 0.085 \\
\hline & HDL_C & $98.38 \pm 6.247$ & $104.31 \pm 4.93$ & $95.57 \pm 9.295$ & 0.974 \\
\hline & T-Cho & $129.5 \pm 8.179$ & $143.0 \pm 6.479$ & $150.2 \pm 12.169$ & 0.489 \\
\hline & GOT & $5.439 \pm 0.051^{\mathrm{b}}$ & $5.403 \pm 0.039^{\mathrm{a}}$ & $5.441 \pm 0.075^{\mathrm{b}}$ & 0.018 \\
\hline & Amy & $5.294 \pm 0.070$ & $5.275 \pm 0.056$ & $5.405 \pm 0.106$ & 0.768 \\
\hline \multirow{9}{*}{$\begin{array}{c}\text { SNP2 } \\
\text { rs14742436 }\end{array}$} & & $\mathrm{CC}$ & $\mathrm{TC}$ & TT & \\
\hline & Glu & $256.5 \pm 4.599$ & $239.3 \pm 9.479$ & $258.0 \pm 6.920$ & 0.851 \\
\hline & T-Pro & $4.356 \pm 0.108$ & $3.925 \pm 0.222$ & $4.189 \pm 0.162$ & 0.172 \\
\hline & GPT & $2.985 \pm 0.064$ & $3.018 \pm 0.132$ & $2.799 \pm 0.097$ & 0.149 \\
\hline & Cre & $-0.245 \pm 0.051$ & $-0.261 \pm 0.105$ & $-0.273 \pm 0.07$ & 0.847 \\
\hline & HDL_C & $101.86 \pm 4.484$ & $87.78 \pm 9.243$ & $108.61 \pm 6.748$ & 0.727 \\
\hline & T-Cho & $139.6 \pm 5.872$ & $143.5 \pm 12.102$ & $139.7 \pm 8.845$ & 0.779 \\
\hline & GOT & $5.424 \pm 0.036$ & $5.433 \pm 0.074$ & $5.426 \pm 0.054$ & 0.872 \\
\hline & Amy & $5.359 \pm 0.050$ & $5.343 \pm 0.105$ & $5.271 \pm 0.077$ & 0.302 \\
\hline
\end{tabular}

${ }^{1}$ Glu: glucose (mg/dL), T-Pro: total protein (g/dL), GPT: glutamic-pyruvic transaminase (IU/L), Cre: creatinine (mg/dL), HDL_C: high density lipoprotein cholesterol (mg/dL), T-Cho: total cholesterol (mg/dL), GOT: glutamic oxaloacetic transaminase, Amy: amylase (IU/L).

${ }^{2}$ Least square means for serum clinical-chemical traits adjusted for fixed effect.

${ }^{\mathrm{a}, \mathrm{b}}$ Means within a row with no common superscript differ significantly $(P<0.05)$. 
et al. (2014) reported that heterozygous state of this SNP can give higher live weight, carcass weight, eviscerated weight and breast muscle weight.

Previous QTL and genome wide association studies in chicken described elsewhere (Gu et al., 2011; Nassar et al., 2013) identified TBC1D1 gene located in the confidence interval of QTL region on GGA4, associated with the visceral, subcutaneous neck and total adipose tissue, body weight and growth rate during different stage of their development. This region also affects the fat mass and body mass at 20 weeks of age (Nassar et al., 2015). Interestingly, in several other studies reported, QTL for growth and body weight in the same region where that include the TBC1D1 gene (Zhou et al., 2006; Ambo et al., 2009). Moreover, this gene has critical roles in regulation of glucose and lipid metabolism in skeletal muscle and body energy homeostasis (Fontanesi et al., 2013). TBC1D1 gene also shows tissue specific expression in several other tissues such as brain, breast, heart and liver (Stone et al., 2006). Investigation on the role of TBC1D1 in insulin signaling and metabolism in skeletal muscle describe that unphosphyorylated TBC1D1 state tightly bind to the GLUT4 molecules and reduce the rate of glucose transport into cell (Sano et al., 2003; Taniguchi et al., 2006). In contrast, TBC1D1 has a negative impact on the uptake of fatty acids and fatty acid oxidation. Moreover, TBC1D1 was identified as a third most significant marker associated with fatness in pig (Fontanesi et al., 2011, 2012). These findings suggest that variations in TBC1D1 gene may affect the growth and carcass traits.

Serum Glutamic Oxaloacetic transaminase (sGOT) is also known as aspartate transaminase (AST) is responsible for catalyzes the reversible transamination between L-aspartate and 2-oxoglutarate to form oxaloacetate and glutamate. sGOT found in liver, heart, skeletal muscle and brain where it involves in glutamine-cycling pathway (Sookoian and Pirola, 2012). Several environment factors other than genetic effects were reported for elevated GOT level in serum in chicken (Elaroussi et al., 2008). Moreover, authors reported that a significant association with insulin resistance with glutamine, glutamate and the ratio between glutamine and glutamate. Thereby, involvement of sGOT in glutamine-cycling pathway (Sookoian and Pirola, 2012).
In our study, we have focused only two SNPs in TBC1D1 gene. Nevertheless, several of other SNPs in TBC1D1 gene are remained to analyze for their effects on growth, meat quality traits in chicken. Based on the current results, we can suggest that TBC1D1 gene have significant effect on growth traits. Therefore, more association studies required to evaluate and validate the effect of TBC1D1 gene on growth traits in chicken.

\section{ACKNOWLEDGMENT}

This work was supported by research fund of Chungnam National University.

\section{REFERENCES}

Ambo M, Moura, ASAMT, Ledur MC, Pinto LFB, Baron EE, Ruy DC, Nones K, Campos RLR, Boschiero C, Burt DW, Coutinho LL 2009 Quantitative trait loci for performance traits in a broiler $\times$ layer cross. Anim Genet 40(2): 200-208.

Cahyadi M, Jo C, Lee JH 2014 Quantitative trait loci and candidate genes for the economic traits in meat-type chicken. Worlds Poult Sci J 70(2):329-342.

Cahyadi M, Park HB, Seo DW, Jin S, Choi N, Heo KN, Kang BS, Jo C, Lee JH 2016 Variance component quantitative trait locus analysis for body weight traits in purebred Korean native chicken. Asian-Australas J Anim Sci 29(1): 43-50.

Dekkers JCM, Van der werf J 2007 Marker-assisted selection in livestock - Case studies, Marker-assisted selection, Current Status and Future Perspectives in Crops, Livestock, Forestry and Fish. ISBN: 978-92-5-105717-9. FAO Rome.

Dokas J, Chadt A, Joost HG, Al-hasani H 2016 Tbc1d1 deletion suppresses obesity in leptin-deficient mice. Int $\mathrm{J}$ Obes 40(8):1242-1249.

Elaroussi MA, Mohamed FR, Elgendy MS, El barkouky EM, Abdou AM, Hatab MH 2008 Ochratoxicosis in broiler chickens: Functional and histological changes in target organs. Int J Poult Sci 7(5):414-422.

Fan WL, Ng CS, Chen CF, LU MYJ, Chen YH, Liu CJ, Wu 
SM, Chen CK, Chen JJ, Mao CT, Lai YT, Lo WS, Chang WH, Li WH 2013 Genome-wide patterns of genetic variation in two domestic chickens. Genome Biol Evol 5(7):1367-1392.

Fontanesi L, Bertolini F 2013 The TBC1D1 gene: Structure, function, and association with obesity and related traits, vitamins and hormones. Elsevier Inc 61(4):78-92.

Fontanesi L, Colombo M, Tognazzi L, Scotti E, Buttazzoni L, Dall'Olio S, Davoli R, Russo V 2011 The porcine TBC1D1 gene: Mapping, SNP identification, and association study with meat, carcass and production traits in Italian heavy pigs. Mol Biol Rep 38(2):1425-1431.

Fontanesi L, Galimberti G, Calò DG, Fronza R, Martelli PL, Scotti E, Colombo M, Schiavo G, Casadio R, Buttazzoni L, Russo V 2012 Identification and association analysis of several hundred single nucleotide polymorphisms within candidate genes for back fat thickness in Italian Large White pigs using a selective genotyping approach. J Anim Sci 90(8):2450-2464.

Gu X, Feng C, Ma L, Song C, Wang Y, Da Y, LI H, Chen $\mathrm{K}$, Ye S, Ge C, Hu X and Li N 2011 Genome-wide association study of body weight in chicken $\mathrm{F} 2$ resource population. PLoS ONE 6:e21872.

Hocking PM 2005 Review of QTL mapping results in chickens. Worlds Poult Sci J 61(2):215-226.

Howard JT, Jiao S, Tiezzi F, Huang Y, Gray KA, Maltecca C 2015 Genome-wide association study on legendre random regression coefficients for the growth and feed intake trajectory on Duroc Boars. BMC Genet 16:59.

Nassar MK, Goraga ZS, Brockmann GA 2012 Quantitative trait loci segregating in crosses between New Hampshire and White Leghorn chicken lines: III. fat deposition and intramuscular fat content. Anim Genet 44(1):62-68.

Nassar MK, Goraga ZS, Brockmann GA 2015 Quantitative trait loci segregating in crosses between New Hampshire and White Leghorn chicken lines: IV. Growth performance. Anim Genet 46(4):441-446.

Peng YD, Xu HY, Ye F, Lan X, Peng X, Rustempašić A, Yin HD, Zhao XL, Liu YP, Zhu Q, Wang Y 2015 Effects of sex and age on chicken TBC1D1 gene mRNA expression. Genet Mol Res 14(3):7704-7714.
Rubin CJ, Zody MC, Eriksson J, Meadows JRS, Sherwood E, Webster MT, Jiang L, Ingman M, Sharpe T, Ka S, Hallböök F, Besnier F, Carlborg R, Bedhom B, TixierBoichard M, Jensen P, Siegel P, Lindblad-Toh K, Andersson L 2010 Whole-genome resequencing reveals loci under selection during chicken domestication. Nature 464(7288):587-591.

Sano H, Kane S, Sano E, Miinea CP, Asara JM, Lane WS, Garner CW, Lienhard GE 2003 Insulin-stimulated phosphorylation of a Rab GTPase-activating protein regulates GLUT4 translocation. J Bio 278(17):14599-14602.

Seo D, Park H, Choi N, Jin S, Heo KN, Jo C, Gotoh T, Lee JH 2016 Association of SNPs in AMY1A and AMY2A genes with chicken meat quality and clinical-chemical traits in chicken. J Fac Agr Kyushu Univ 61:121-125.

Sookoian S, Pirola CJ 2012 Alanine and aspartate aminotransferase and glutamine-cycling pathway: Their roles in pathogenesis of metabolic syndrome. World J Gastroenterol 18(29):3775-3781.

Stone S, Abkevich V, Russell DL, Riley R, Timms K, Tran T, Trem D, Frank D, Jammulapati S, Neff CD, Iliev D, Gress R, He G, Frech GC, Adams TD, Skolnick MH, Lanchbury JS, Gutin A, Hunt SC, Shattuck D 2006 TBC1D1 is a candidate for a severe obesity gene and evidence for a gene/ gene interaction in obesity predisposition. Hum Mol Genet 15(18):2709-2720.

Taniguchi CM, Emanuelli B, Kahn CR 2006 Critical nodes in signalling pathways: Insights into insulin action. Nat Rev Mol Cell Biol 7(2):85-96.

van der Beek S, van Arendonk JAM 1996 Marker-assisted selection in an outbred poultry breeding nucleus. Anim Sci 62(1):171-180.

Wang Y, Xu HY, Gilbert ER, Peng X, Zhao XL, Liu YP, Zhu Q 2014 Detection of SNPs in the TBC1D1 gene and their association with carcass traits in chicken. Gene 547(2):288-294.

Warnes G 2012 Population Genetics, Manual Package 'Genetics'. Pages 1-42.

Yang ZJ, Fu L, Zhang GW, Yang Y, Chen SY, Wang J, Lai SJ 2013 Identification and association of SNPs in TBC1D1 gene with growth traits in two rabbit breeds. Asian- 
Australas J Anim Sci 26(11):1529-1535.

Zhou N, Deeb N, Evock-Clover CM, Ashwell CM, Lamont SJ 2006 Genome-wide linkage analysis to identify chromosomal regions affecting phenotypic traits in the chicken. I. Growth and average daily gain. Poult Sci 85(10):17001711.
Zhu M, Zhao S 2007 Candidate gene identification approach: Progress and challenges Int J Biol Sci 3(7):420-427.

Received Nov. 27, 2018, Revised Dec. 25, 2018, Accepted Dec. 27,2018 